\title{
Dendritic and langerhans cells respond to $A \beta$ peptides differently: implication for AD immunotherapy
}

\author{
Jiang Cheng ${ }^{1,2}$, Xiaoyang Lin 2,3, David Morgan ${ }^{3,4}$, Marcia Gordon ${ }^{3,4}$, Xi Chen ${ }^{5}$, Zhen- \\ Hai Wang ${ }^{1}$, Hai-Ning Li ${ }^{1}$, Lan-Jie He ${ }^{6}$, Shu-Feng $\mathrm{Zhou}^{2,7}$ and Chuanhai $\mathrm{CaO}^{2,3}$ \\ ${ }^{1}$ Department of Neurology, General Hospital of Ningxia Medical University, Yinchuan, Ningxia, China \\ 2 Department of Pharmaceutical Sciences, College of Pharmacy, University of South Florida, Tampa, FL, USA \\ ${ }^{3}$ USF-Health Byrd Alzheimer's Institute University of South Florida, Tampa, FL, USA \\ 4 Department of Molecular Pharmacology and Physiology University of South Florida, Tampa, FL, USA \\ ${ }^{5}$ Department of Colorectal Surgery, General Hospital of Ningxia Medical University, Yinchuan, Ningxia, China \\ ${ }^{6}$ Department of Endocrinology, General Hospital of Ningxia Medical University, Yinchuan, Ningxia, China \\ ${ }^{7}$ Guizhou Provincial Key Laboratory for Regenerative Medicine, Stem Cell and Tissue Engineering Research Center \& Sino-US \\ Joint Laboratory for Medical Sciences, Guiyang Medical University, Guiyang, Guizhou, China
}

Correspondence to: Chuanhai Cao, email: ccao@health.usf.edu

Shufeng Zhou, email: szhou@health.usf.edu

Keywords: dendritic cell, langerhans cell, vaccine, amyloid beta peptide, T-cell epitope

Received: July 10,2015 Accepted: September 08, $2015 \quad$ Published: October 14, 2015

This is an open-access article distributed under the terms of the Creative Commons Attribution License, which permits unrestricted use, distribution, and reproduction in any medium, provided the original author and source are credited.

\section{ABSTRACT}

Both wild-type and mutated beta-amyloid $(A \beta)$ peptides can elicit an immune response when delivered subcutaneously. However, only mutated forms of $A \beta$ can sensitize dendritic cells when administered intravenously or intraperitoneally. To understand the role of mutation and delivery routes in creating immune responses, and the function of dendritic cells as therapeutic agents, we used fluorescentconjugated WT AB1-40 (WT40) and artificially mutated Aß1-40 (22W40) peptides to treat dendritic and Langerhans cells from young and/or old mice at different time points. The cell types were analyzed by flow cytometry and confocal microscopy to identify differences in function and antigen presentation, and Luminex and Western blots for cell activation and associated mechanisms. Our results demonstrated that the artificial mutant, 22W40, enhanced dendritic cell's phagocytosis and antigen presentation better than the WT40. Interestingly, Langerhans cells were more effective at early presentation. The artificial mutant $22 \mathrm{~W} 40$ increased CD8 $a^{+}$dendritic cells, CD8 ${ }^{+} \mathrm{T}$-cells, and IFN-Y production when co-cultured with self-lymphocytes and dendritic cells from aged mice (30-month-old). Here, the $22 \mathrm{~W} 40$ mutant peptide has been found to be potent enough to activate DCs, and that dendritic cell-based therapy may be a more effective treatment for age-related diseases, such as Alzheimer's disease (AD).

\section{INTRODUCTION}

Immunotherapy has been widely implemented in the treatment of various types of diseases, spanning from foreign pathogens to autoimmune origins. Traditionally, immunotherapies can be grouped as either vaccine or antibody/anti-sera therapy. Vaccination, also known as active immunotherapy, works by injecting an antigen into the subject to induce an antibody response to the injected antigen. This method was originally designed for prophylactic purposes because it requires incubation period, about 2 weeks [1] and even longer for the elderly $[2,3]$,to generate protection. Therefore, vaccination is generally not used while the person is already affected by the pathogen. However, antibody therapy, otherwise known as passive immunotherapy, aims to deliver antibody 
or antisera into a subject who may be already affected by the pathogen. Although passive immunotherapy works ideally for those already showing disease symptoms, long term use of this method can induce serum sickness, where the body produces antibodies against the injected sera. In addition, the relatively high cost associated with this method limits its preference.

With advancements in technology, vaccination methods have been expanded to treat many other diseases such as cancer, diabetes, and arthritis. An HPV vaccine that was recently licensed is currently making strides at eliminating HPV-derived cervical cancers [4]. Almost a decade ago, there was a breakthrough in neurodegenerative disease vaccine development when Elan pharmaceutical launched the first clinical trial of Alzheimer's vaccine developed from A $\beta$ peptide plus a strong adjuvant. Although the clinical trial was suspended by the FDA due to strong adverse effects $[5,6]$, the fundamental work opened a new era for immunotherapies against neurodegenerative diseases. Currently, the idea of immunotherapy has been extended to any therapy that works via modulation of the immune system, and from this, we are starting to see vaccines become less of a prophylactic measure to more of a treatment procedure.

Cell-based immunotherapies have become a dominant therapeutic method for cancer because of its selfdonor property. Based on this same property, the approach has been evaluated for AD treatment in mouse model [7, 8]. With progress in knowledge on dendritic cells, more potent therapeutic vaccines have been developed for use in disease treatment. Dendritic cells (DCs) are considered as the professional antigen presenting cells (APC), and play a very critical role in antigen presentation to the immune system. They also serve as mediators between the innate immune system and the adaptive immune system. The role of APCs in neurodegenerative diseases is scarcely studied, and so, understanding the role and properties of DCs in AD will help us better unravel the mechanism for Alzheimer's disease progression, thus hopefully leading to a solution.

Both mature and immature DCs can be found in the circulatory system; they are specialized for antigen uptake, procession and presentation to T-cells [9, 10]. For a long time, immunologists have believed that DCs from peripheral blood were the same as those residing in the skin, known as Langerhans cells (LCs). However, DCs in the blood comprise of both mature and immature phenotypes, whereas Langerhans cells (LCs) are immature cells of the DC system. LCs also take up antigens, but only in the epidermis. In addition, DCs and LCs carry different surface markers, implying that they may have different functions. Antigen-stimulated DCs and LCs migrate to secondary lymphoid organs to stimulate T-cells, and initiate an immune response. A recent discovery of the existence of lymphatic system in the brain is an impetus for DCs based vaccine for brain diseases [11]. As originally discovered by Alois Alzheimer, the brain of an $\mathrm{AD}$ patient is overwhelmed with $\mathrm{A} \beta-42 / 43$ peptide plaque buildup [12]. This extracellular protein inspired the use of the misfolded molecules, contained in the plaques, as the antigen component of a vaccine. It was discovered that $A \beta 1-42$ peptide contained two very strong $B$ cell epitopes [13], and one major T-cell epitope [14, 15]. It is interesting to note that beta-amyloid peptide sequence is highly conserved among mammalian species [16], thus a prompt that it might have important biological function(s), although this is/ are yet to be precisely elucidated [17]. Not with standing, the peptide has been reported to show some protection against oxidative stress in the brain $[18,19]$, to aid in cholesterol transport [20], and have antimicrobial activity $[21,22]$. The $A \beta$ peptide alone has been shown to induce antibody response, without the use of an adjuvant [23]. This indicates that $A \beta 1-42$ is very immunogenic and may play very important role in immune balance or tolerance. Interestingly, known human mutations in the T-cell epitope of $A \beta$ have been linked to different clinical symptoms: patients with the Dutch mutation predominantly show hemorrhaging in the brain $[24,25]$, while patients with the Flemish mutation demonstrate both AD-like amyloid deposition and hemorrhaging [26]. It has also been suggested that these mutations in the T-cell epitope enhanced the production of $A \beta$ plaques, and therefore may be directly related to the early onset of the disease $[27,28]$. In fact, when mutant $A \beta$ peptide was used as vaccine, it showed more immunogenicity than the wildtype form [29].

Currently, many cell-based vaccines use peptidesensitized DCs with less focus on LCs. However, most vaccines used for disease prevention are delivered via intradermal injection, and work through the activation of LCs. Thus, it is extremely important to understand the differences between how DCs and LCs work, upon antigen stimulation, when used in vaccination. In our previous study, we proved that the WT form of A $\beta$ peptide is immunogenic and even more profound was the immunogenicity of the mutant variants (Flemish and Dutch) [29]. When we used wild-type and mutant peptide-sensitized DCs as vaccines, cells sensitized with only the mutant peptides could induce antibody response without triggering inflammation [14]. Meanwhile, when the same peptides were subcutaneously injected into mice, both the wild-type and mutant forms induced antibody response [30, 31]. This interesting observation prompted in us the idea that the same peptide may act differently in the body, depending on the route of administration, and that verifying this phenomena may help in finding and developing safe and effective vaccines.

In line with this, we sensitized bone marrow-derived DCs (BMDCs) and skin-isolated Langerhans cells (LCs) with wild-type and mutant (mutated T-cell epitope, which ranges from among amino acids 17 to 24 , using both known human and artificial mutations) $\mathrm{A} \beta$ peptides to 
investigate the significance of mutation and delivery route in vaccine development.

\section{RESULTS}

Antigen presentation ability of BMDCs in youngC57/B6 mice shows no difference between florescent labeled wild-type and mutant A $\beta 1-40$ peptide

We used bone marrow derived dendritic cells from 2 months old C57/B6 mice, and sensitized them with florescent labeled wild and artificially mutated $22 \mathrm{WA} \beta 1$ 40 peptides. We then analyzed MHC class II and $\mathrm{A} \beta$ expression levels at two different time points $(12 \mathrm{~h}$ and $24 \mathrm{~h})$. There was no significant difference in the levels of both MHC II and A $\beta$ on DCs treated with either the mutant or wild-type peptide $(P>0.05, n=4)$ (Figure 1A and 1B). To further verify this, we employed confocal microscopy to visualize the location of the antigens. By fluorescence, there seem to be more MHC II/CD11c localization on DCs stimulated with mutant $A \beta$ peptides (Figure 2).

Langerhans cells (LCs) from young C57/B6 mice show significant differences in antigen presentation ability between florescent labeled wild-type and mutant A $\beta 1-40$ peptide

When LCs were treated with the same peptide regimen as the DCs, significant differences in the levels of both MHC II and A $\beta$ peptide uptake were observed in a time-dependent manner (Figure 3A, 3B). Additionally, significantly higher double positive cells for CD207 and MHCII were observed $(n=4, P<0.05)$. There were also significant differences in the mean fluorescent intensity (MFI) in the $22 \mathrm{~W}$ mutant peptide-treated group than their wild-type cohort $(n=4, P<0.05)$. Confocal microscopy confirmed this observation (Figure 4).

\section{The differences of antigen presentation and $T$ cell activation between DCs and LCs}

To identify the ability of antigen presentation, antigen sensitized DCs or LCs were co-cultured with splenocytes. DCs and LCs were allowed 12 and 24 hours to uptake either the control, WT or $22 \mathrm{~W}$ peptides in a cell culture and then co-cultured with splenocytes. Cell surface marker analysis on these various cells by flow cytometry revealed that the percentage of $\mathrm{CD} \alpha^{+}$cells was higher in the $22 \mathrm{~W}$-stimulated DC-splenocytes coculture group as compared with the control group after 24 hours of incubation (Figure 5A, left graph). The LC group, however, did not show any significant differences between the groups (Figure 5A, right graph). This indicates increased uptake activity of DC cells when challenged with $22 \mathrm{~W}$ mutant peptide as compared with either control or WT peptides. The percentage of peptide ${ }^{+} \mathrm{CD} 8 \alpha^{+}$(doublepositive) cells was significantly higher in the mutated group among all peptide groups at all-time points in the DC culture (Figure 5B, left graph). Though in the LC grouping, significant differences were found between the $22 \mathrm{~W}$ and the control, and the $22 \mathrm{~W}$ versus the WT peptides at $12 \mathrm{~h}$ and $24 \mathrm{~h}$, none was found between the control vs. the WT peptides at either time point (Figure $5 \mathrm{~B}$, right graph). The percentage of $\mathrm{CD}^{+}$cells showed no significant differences among all the groups and time points for either the DC or LC groupings (Figure 5C). Finally, we measured the concentration of IFN- $\gamma$ in the coculture supernatant. There were significantly higher levels in $22 \mathrm{~W}-\mathrm{DC}$ samples than in WT-DC at $24 \mathrm{~h}$ time point, and higher levels in the $22 \mathrm{~W}$-LC than in the control-LC during the same period (Figure 5D).

Aged mice have the ability to differentiate DC, and mutated peptide better sensitize them

After demonstrating the existence of differential antigen presentation by DCs of young mice, we wanted to know the functional activity of these cells in older mice with regards to antigen presentation. Using the same approach as in the young mice, we discovered that older mice (30-months old) still had functional DCs with able antigen presentation ability (Figure 6). Also, the percentages of CD11 $\mathrm{c}^{+}$peptide ${ }^{+}$double-positive cells (Figure 6A), CD8 $\alpha^{+}$cells (Figure 6B), $\mathrm{MHCII}^{+}$peptide ${ }^{+}$ double-positive cells (Figure 6C), and $\mathrm{MHCII}^{+} \mathrm{CD} 8 \alpha^{+}$ double-positive cells (Figure 6D) were significantly higher in $22 \mathrm{~W}$-mutant DCs than in WT or control peptide treated DCs $(n=4, P<0.05)$.

We also included an A $\beta$ 42-1 peptide, a reverse of the normal $A \beta$ 1-42 peptide sequence, as a control antigen to stimulate the DCs from old mice. This was to help clarify whether the observed antigen response was $\mathrm{A} \beta$-specific or just a general antigenicity response due to declined immune function. We discovered that only the A $\beta$ 1-40 WT and A $\beta$ 1-40 22W could successfully sensitize DCs (Figure $7 \mathrm{~A}, 7 \mathrm{~B}, 7 \mathrm{C}$ ). There were significant differences in percentages of $\mathrm{CD} 8 \alpha^{+}$cells (Figure 7B) and $\mathrm{MHCII}^{+} \mathrm{CD} 8 \alpha^{+}$double-positive cells (Figure $7 \mathrm{C}$ ). The $22 \mathrm{~W}$ mutant peptide significantly activated these aged DCs than any other peptide treatment in this study.

\section{No differences in inflammatory cytokine secretion by antigen sensitized DCs}

There were significant immune response differences when $A \beta 1-40 \mathrm{WT}$ and $\mathrm{A} \beta 1-4022 \mathrm{~W}$ were used to sensitize 
A
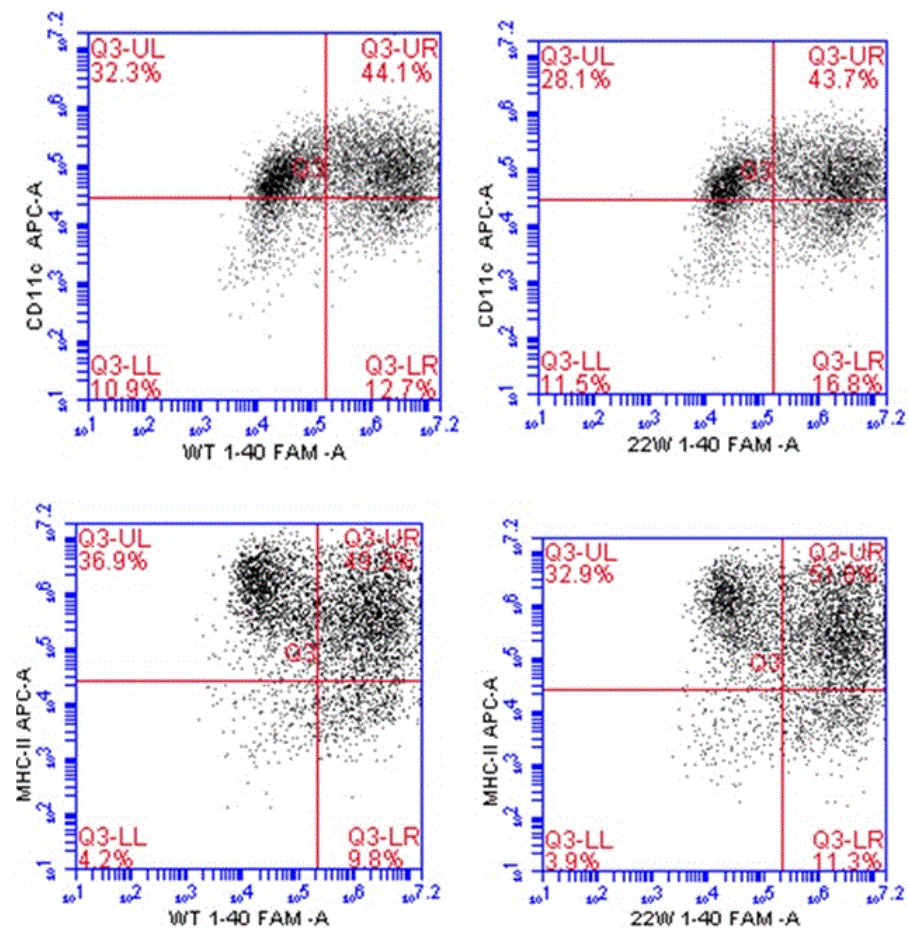

B
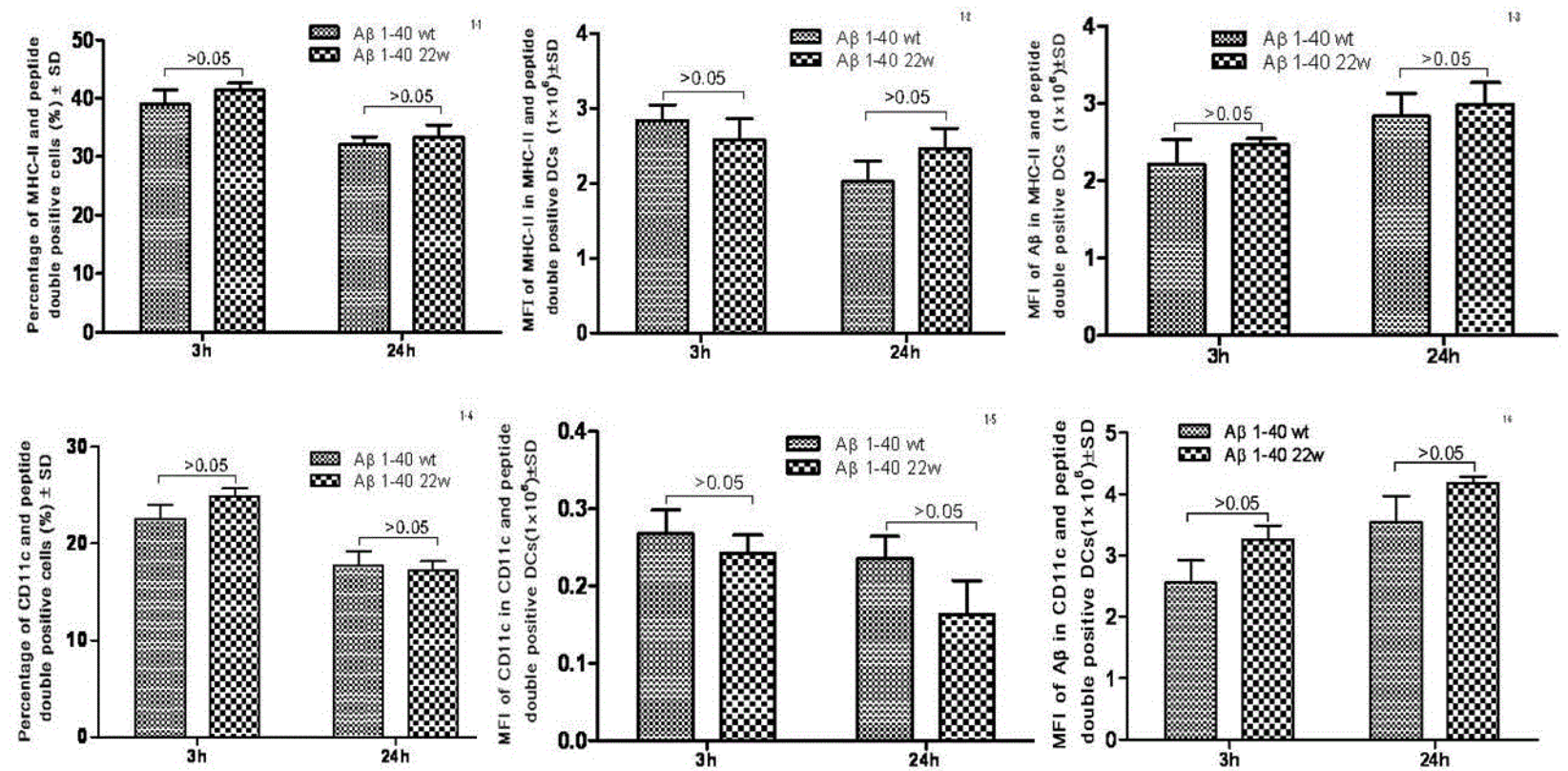

Figure 1: Antigen presentation results of DCs sensitized by wild-type FAM-Aß 1-40 (WT FAM-A $\beta$ 1-40), and FAM-

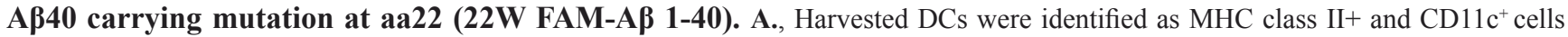
using flow cytometry assay after staining with different florescent conjugated antibodies. A (top) is the flow cytometry diagram for antigen stimulated DCs at different time points. Graphs in B. demonstrate the percentage of MHCII (top row) or CD11c (bottom row) in the peptide double positive DCs, the mean fluorescent intensity (MFI) of the peptide in the double positive DCs (middle), and the MFI of the MHCII (top right) or the CD11c (bottom right) in the double positive DCs. There is no statistical significant differences between two antigens $(P$ $>0.05, n=4)$. 
DCs as a vaccine. To investigate the role of specific cell population in the immune response, we examined cytokine production by DCs from mice of different genotypes (Figure 8). Overall, there was no significant, but just marginal, differences attributed to genotype and peptide stimulation $(n=4, P>0.05)$.

\section{Peptide sensitized DCs vaccine rely on the mutated $T$ cell epitope but not the MHCI affinity and peptide aggregation}

Western blot analysis was performed on a number of different peptides based on different mutations in beta amyloid (Figure 9). The lowest affinity mutations (24M mutation) showed the highest levels of aggregation (Lanes 12-14), and the WT (Lanes 1-4) had higher proaggregation property compared with $22 \mathrm{~W}$ mutant (Lanes 9-11), as demonstrated by the number of oligomer isoforms from the Western blot. The WT form of A $\beta$ also showed much lower affinity for MHC Class I.

\section{DISCUSSION}

Many studies have reported the link that exists between the immune system and neurological disease, including AD [32-35]. Currently, mounting research have focused on immunotherapies and T-cell therapy as major approaches to treating these disorders $[7,8,36]$. It has been suggested that targeting the immune system may be the safer and more effective treatment approach for AD $[37,38]$. With regards to this treatment, dendritic cells (DCs) are the favorable cell types used in immunotherapy, because they can modulate both the innate and acquired immune systems with autologous cells, and because of this, is currently being used exponentially in treatment of disease, such as cancer [39, 40].
About 15 years ago, injection of a novel $\mathrm{A} \beta$ peptide vaccine generated great interest in the fields of neuroscience and $\mathrm{AD}$, showing promise in basic research but this was suspended in clinical trial due to adverse effects. Recently, our lab developed a novel and safe vaccine against AD using peptide-sensitized DCs [14, 41-44]. Since then, we have also focused and established a BMDC culture method and repeatedly tested our peptide-sensitized DCs as a therapeutic vaccine for AD. The purity of the DCs derived with this method can be more than 95\% when detected with MHCII and CD11c as markers $[14,41,42]$. In the vaccine development process, we also noticed that WT and mutated (22W) A $\beta$ could induce immune response when delivered by subcutaneous injection, with or without an adjuvant. However, the WT peptide failed to induce the same response when used to sensitize DCs alone, and that all peptides with a mutated $\mathrm{T}$ cell epitope could induce antibody response, thus the reason for focusing on $22 \mathrm{~W}$ peptide only in this study. We also investigated difference in activation of DCs and LCs by the wild type and mutant type peptides.

To elucidate the function of our artificial mutant peptide in DCs sensitization and the differences between BMDCs and LCs, we conducted several experiments on both young and old mice to evaluate the function of these cells in order to address this age related disease (AD). There was no significant difference in antigen presentation (A $\beta$ florescence) or MHCII expression level between wildtype and mutant peptide-sensitize DCs (Figure 1A, 1B), but we did observed slightly more fluorescence from the mutant peptide-treated cells (Figure 2). Our hypothesis is that no difference was observed between the WT and $22 \mathrm{~W}$ mutant peptides because of the relatively young age of the mice. At this age, the immune system is in its prime, and that both peptides are processed with high efficiency. Based on our lab's previous experience, there should be a difference in antigen presentation between the two
A
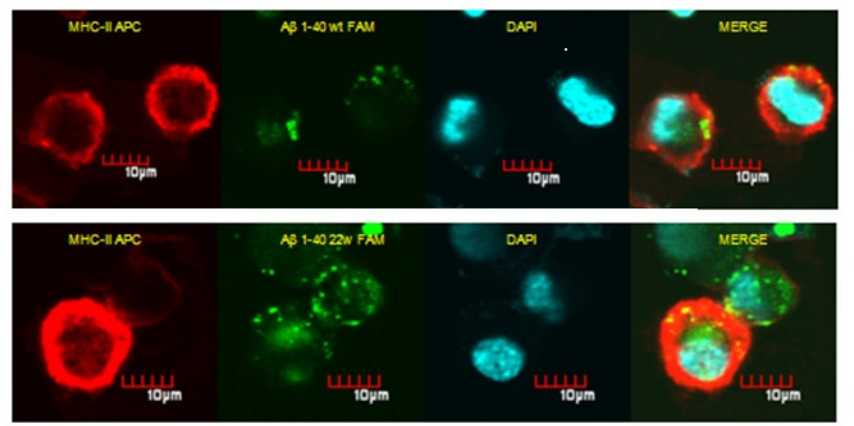

B
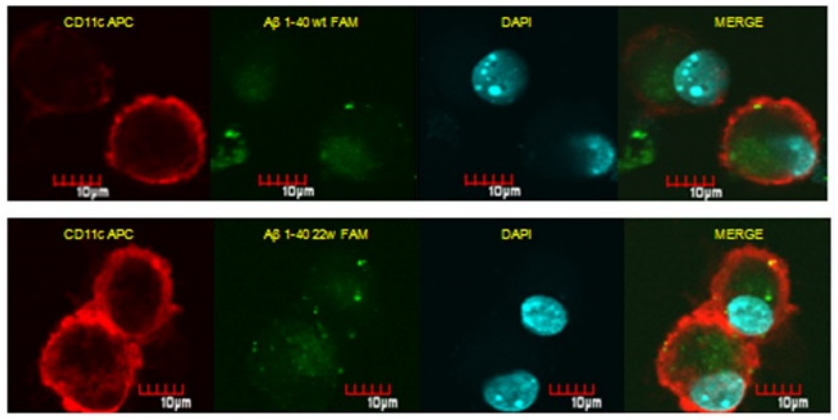

Figure 2: Confocal microscopy images of DCs sensitized by WT and mutant (22W) peptides. BMDCs have the ability to uptake and present antigens on the cell surface. The florescent level here is used as indicator for level of antigen presentation. Cells treated the same as in flow cytometry assay, and attached onto slide by cytospin assay: BMDCs stained for MHC-II/CD11c (red fluorescence), incorporated FAM-A 440 (green fluorescence). A. shows in vitro uptake of FAM-A 440 WT (top) or 22W (bottom) by cultured BMDCs and the corresponding MHC II levels, where B. shows CD11c levels in response to WT (top) or 22W (bottom). In both columns, it seems as if there more localization of $\mathrm{MHCII} / \mathrm{CD} 11 \mathrm{c}$ with $\mathrm{A} \beta$ in mutant peptide-sensitize cells than the wild-type peptide-sensitize cells. 

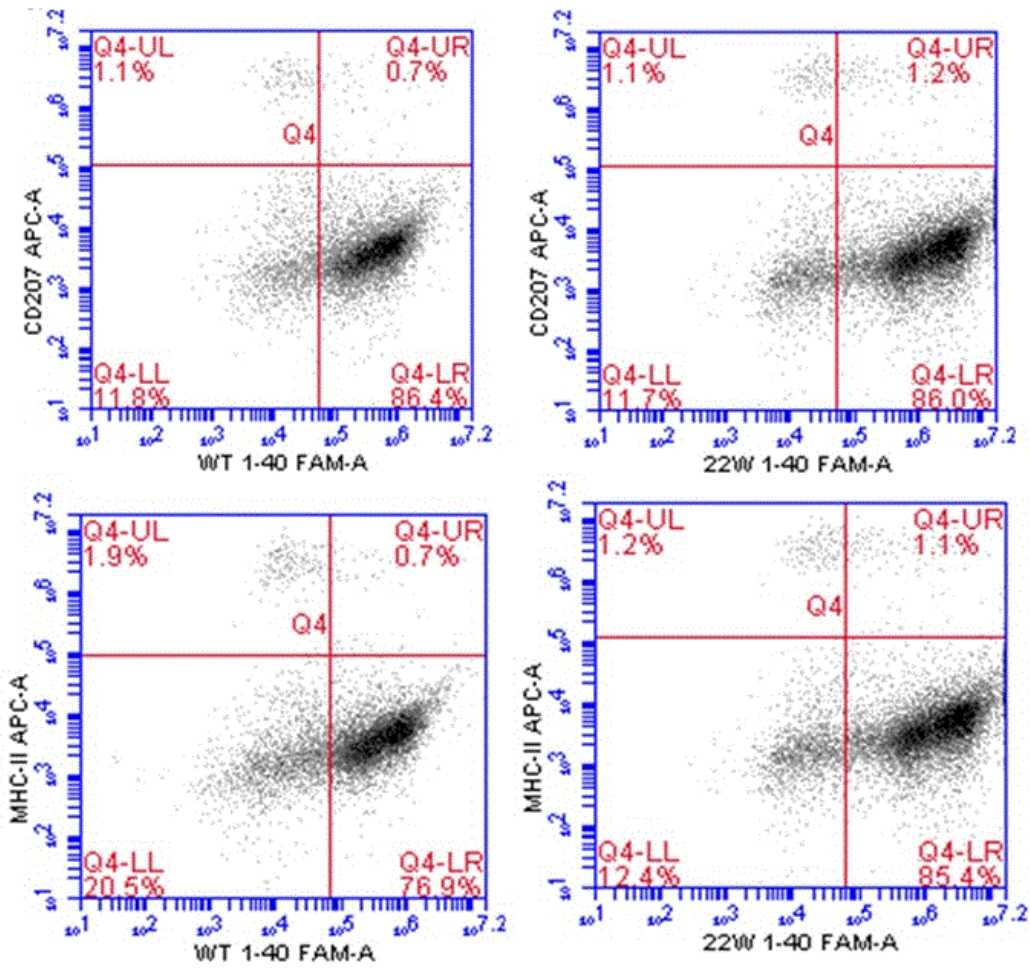

B
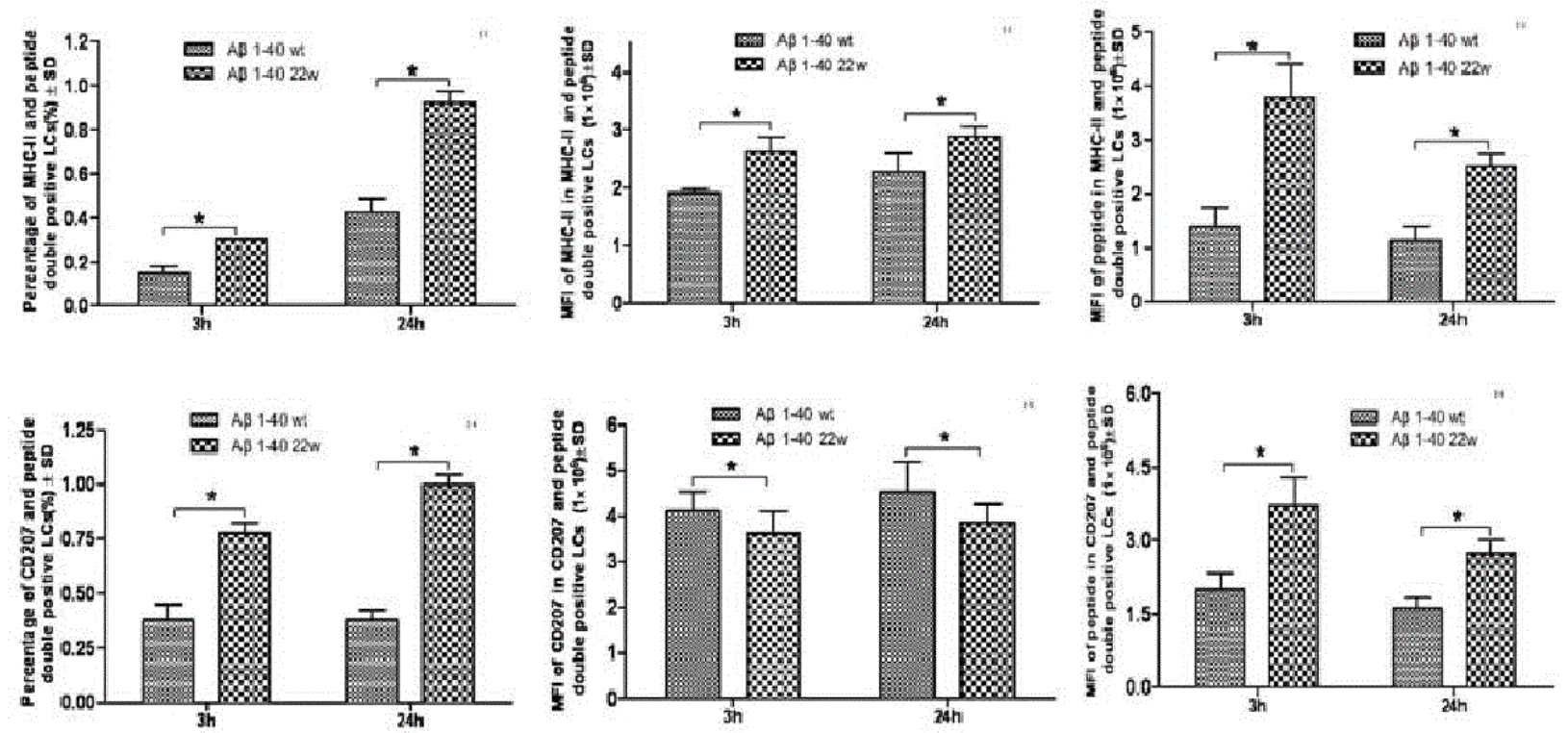

Figure 3: Antigen presentation results of LCs sensitized by wild-type FAM-A $\beta$ 1-40 (WT FAM-A $\beta$ 1-40), and FAMA $\beta 40$ carrying mutation at aa22 (22W FAM-A $\beta$ 1-40). A., Harvested LCs were identified as MHC class II + and CD11 $\mathrm{c}^{+}$cells using flow cytometry assay after staining with different florescent conjugated antibodies. A is the flow cytometry diagram for antigen stimulated LCs at different time points. Graphs in B. demonstrate the percentage of MHCII (top left) or CD207 (bottom left) in the peptide double positive LCs, the mean fluorescent intensity (MFI) of the peptide in the double positive LCs (middle), and the MFI of the MHCII or the CD207 in the double positive LCs. There are significant higher positive cell percentages) and MFI of peptide inside the cells in the mutant peptide treated group than the wild-type peptide treated group $(n=4, P<0.05)$ for both the MHCII and CD207 double positive cells. However, the significances vary for the middle column of graphs comparing the levels of MHCII in the MHCII cells and the levels of CD207 in CD207 cells. 
peptides when mice are treated more frequently and over a longer period of time [31].

When these same peptides were tested in much older mice (30 month old, (Figure 6), the $22 \mathrm{~W}$ mutant peptide strongly sensitized DCs than WT peptide (Figure 7). Here, we assert that possibly, the $22 \mathrm{~W}$ mutant peptide elicited such higher response because it could break DCs' tolerance to $\mathrm{A} \beta$ peptides.

Age-related diseases, like AD, show impaired immune function $[45,46]$, and the immune response in older subjects will most likely be too weak for the body effectively recognize antigens. Therefore when designing a vaccine, a strong adjuvant is usually introduced to help elicit the immune response. This sometimes is too strong in effect, causing massive adverse side-effects as seen in the original Elan pharmaceutical's vaccine for AD. In our study, we have used peptides to sensitize older, 30 month old, mice and our result showed that they effectively sensitize DCs, and more importantly convert to CD8 $\alpha^{+}$ cells. The CD8 $\alpha^{+}$cells can then expand and enhance CD $8^{+}$ T-cell population, causing a strong antiviral and bacterial response. $\mathrm{CD}^{+}$or cytotoxic T-cells plays critical role in fighting infectious disease and cancer, and as older patients are more susceptible to all kinds of infection, this DC vaccine may have unique overlapping benefits.

When LCs from young mice were examined under the same regimen as the DCs, the mutant $22 \mathrm{~W}$ peptide elicited significantly stronger immune response compared to the WT peptide $(P<0.05$, Figures $3 \mathrm{~A}, 3 \mathrm{~B}$, and 4$)$. This result was noticeably different from that of DCs, as the LCs seemed to respond better to the mutant peptide in young mice. This observation we explain to be tolerance related. LCs reside in the epidermis, papillary dermis, and mucosa and carry out specific homeostatic function [47, 48] and may have little or no prior exposure to a fairly unseen antigen in the epithelia, the $\mathrm{A} \beta$ peptide. Therefore,

A
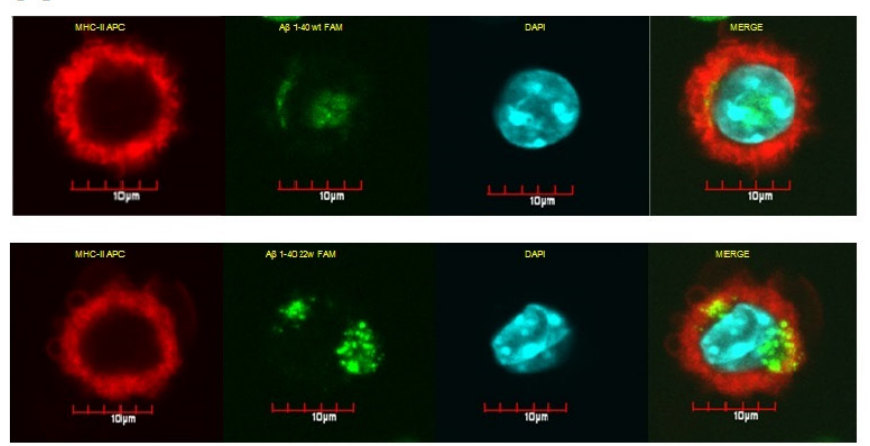

they are less likely to develop tolerance to the peptide, and thus can be readily activated/sensitized by the peptide. On the other hand, DCs which are within the peripheral circulatory system more often encounter peripheral $A \beta$ in the blood and are able to easily/ quickly develop tolerance to this peptide

When LCs and DCs were co-cultured with splenocytes, there was increased uptake in the DC population of $22 \mathrm{~W}$ than the WT (Figure 5). There was also an increase in $\mathrm{CD} 8 \alpha^{+}$cells from the DC co-culture, but not the LC co-culture, and a corresponding increase in the peptide ${ }^{+} \mathrm{CD} 8 \alpha^{+}$double positive co-culture (significant across all levels of measurement) and also of the LCs (significant only when comparing the $22 \mathrm{~W}$ to either the WT or control). We also see LCs as being slightly more potent than DCs here in terms of antigen presentation on the bases of percentage positive cells. However, there were no differences in the population of $\mathrm{CD}^{+}$cells (Figure. 5C). IFN- $\gamma$ concentrations in the supernatants from the co-cultures, revealed higher levels in the $22 \mathrm{~W}$ peptide co-cultures of both DCs and LCs at 24 hours. This is very essential in the demonstration that the mutant peptide promotes cellular, rather than humoral, response as evidenced by the increase in $\mathrm{CD}^{+}$T-cells and IFN- $\gamma$ production.

One of the major concerns for immunotherapy is the safety of treatment because of the close link between inflammation and AD. The effect of most vaccinations is to prime the immune system, but an overtly strong response can be life-threatening to the patient. To test the safeness of the immune response, we assessed a panel of humoral and cellular induced cytokines and chemokines to validate the DC vaccine. Cytokine and chemokine expression profile analysis showed that there were no significant changes across the panels (Figure 8). This suggests that our DC-based vaccine may not induce

\section{B}
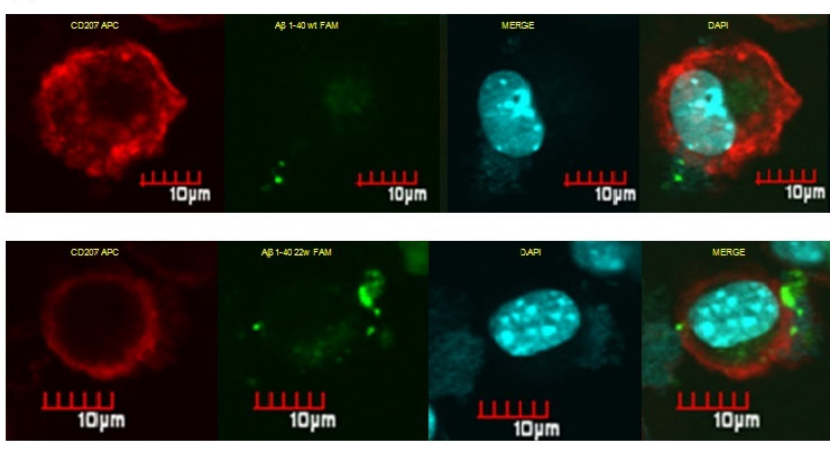

Figure 4: Confocal microscopy pictures of LCs sensitized by different peptides.LCs have the ability of uptake and present antigens on the surface. The florescent level here is used as indicator for antigen presentation. Cells treated the same as in flow cytometry assay, and attached onto slide by cytospin assay: LCs stained for MHC-II/CD11c (red fluorescence), incorporated FAM-A 340 (green fluorescence). The left column of A. demonstrated in vitro uptake of FAM-A $340 \mathrm{WT}$ (top-left) or 22W (bottom-left) by cultured LCs and studied for MHC-II expression. There seems to be more localization of MHCII with A $\beta$ in mutant peptide-sensitize cells than the wild-type peptide-sensitize cells. The right column of B. shows the CD11c expression and A $\beta$ level uptake in the same cell type stimulated with different peptides, either the WT (top) or 22W (bottom) A $\beta$. There is more CD11c expressed and more antigen in the cell in the mutant peptide-sensitize LCs than in wild-type peptide-sensitize LCs. 
A
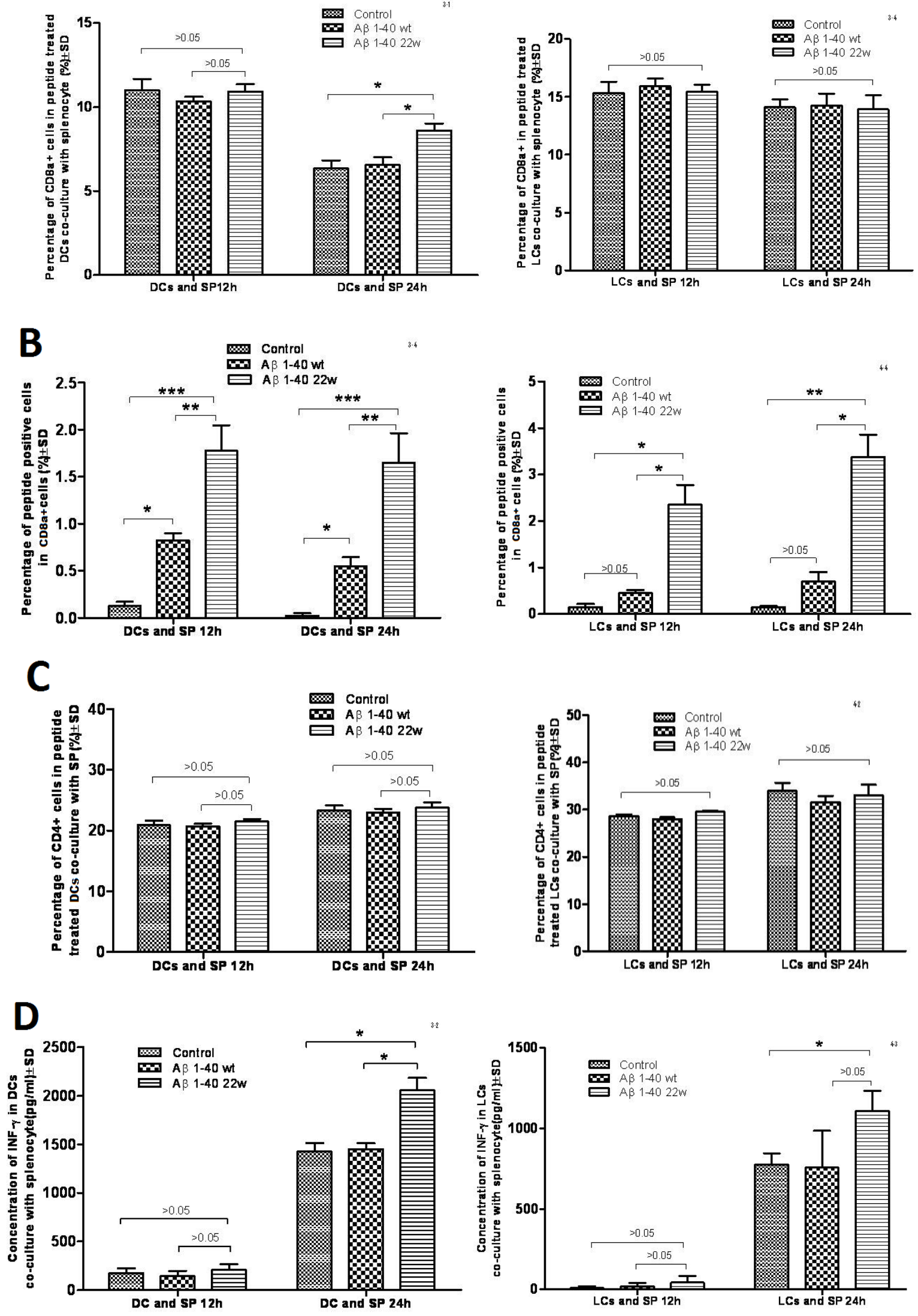
Figure 5: Result of antigen stimulated Dendritic cell (DC) or Langerhans cell (LC) co-cultured with splenocytes. When DCs and LCs were prepared from the mouse, the splenocytes were also harvested and frozen. The antigens were presented and allowed for uptake by the cells. Two days after the antigen stimulation to DCs and LCs, the splenocytes were thawed and placed in the incubator overnight. The cells were then co-cultured together on the third day, and cells were harvested next day and an antibody cocktail was used to stain the cells. In A., the percentage of CD8a+ DCs and LCs when co-cultured with splenocytes at $12 \mathrm{~h}$ and $24 \mathrm{~h}$. At $24 \mathrm{hours}$, there was significant percentage changes in the DCs-splenocytes co-cultured group between two peptides (mutant higher than wild-type and control, $n=4, P<0.05)$ and there is no differences seen in LCs-splenocyte co-cultured group between two peptides at either time point. In B., the percentage of peptide+ cells in CD8a+ cells was measured in the DCs and LCs co-cultured at $12 \mathrm{~h}$ and $24 \mathrm{~h}$. Significances were found for both LCs and DCs cultures between the control, WT, and mutant peptides ( $n=4, P<0.05)$, except for when comparing the control and WT groups in LCs $(P>0.05)$. In C., the percentage of CD4+ T-cells were studied in the DCs and LCs co-cultures with splenocytes at $12 \mathrm{~h}$ and 24h. No significances were found. In D., the concentration of IFN-gamma was studied in the co-culture system at 12 hours and 24 hours. There is a significant difference in the DC population between the control and mutant antigen at the $24 \mathrm{~h}$ time point $(n=4, P<0.05)$. There is also a significance between the mutant and control antigen in the LC population $(n=4, P<0.05)$.

A
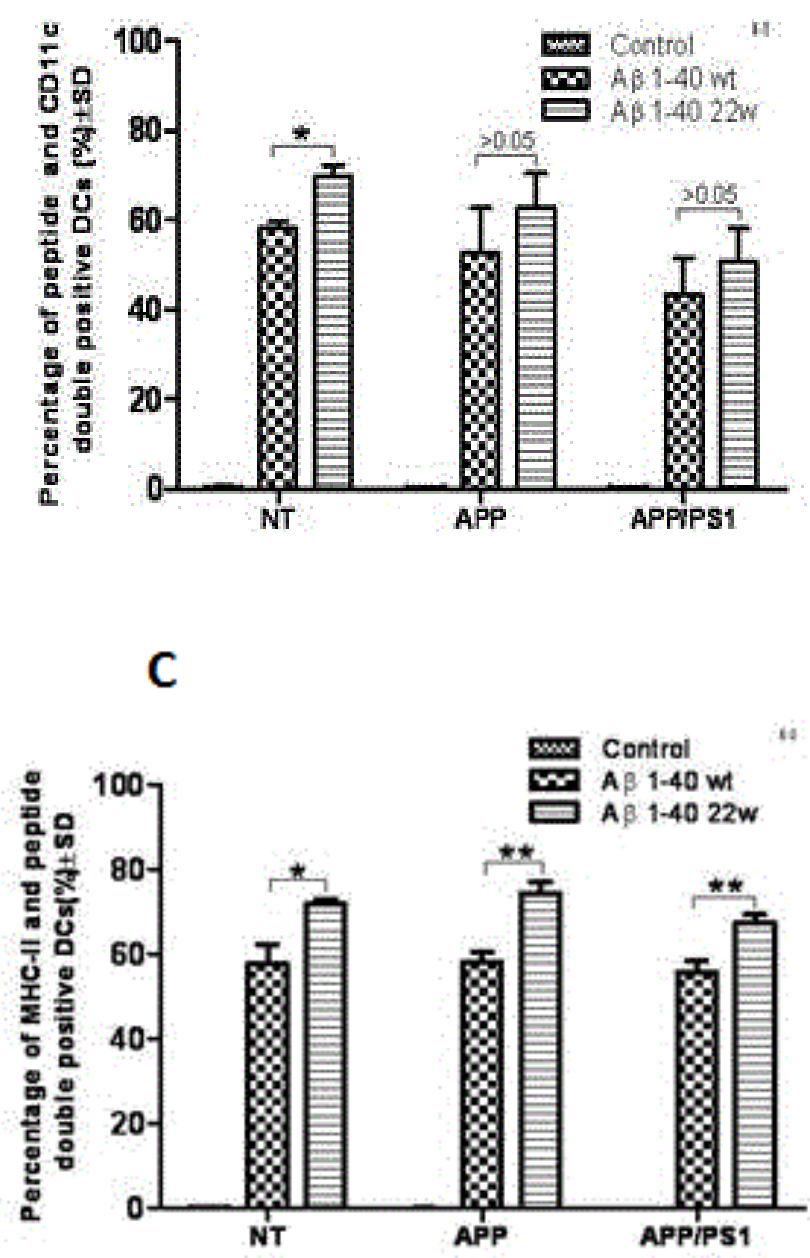

B

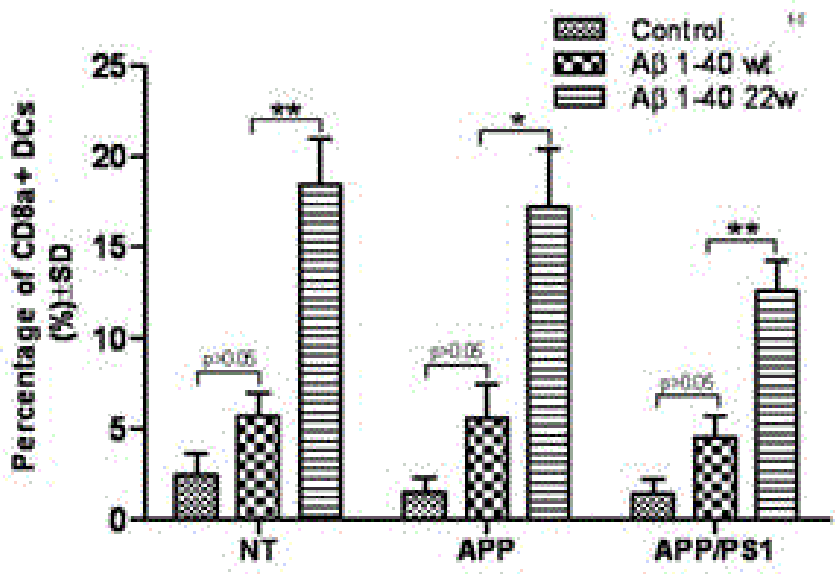

D

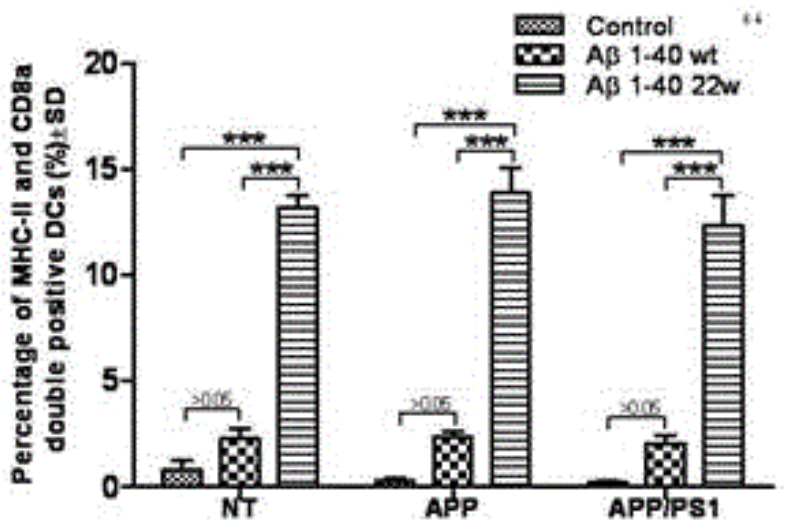

Figure 6: Antigen presentation by DC cells from different genotypes of 30 month old mice. The percentage of the CD11c+peptide + double positive A., CD8a+ B., MHCII + peptide + double positive $\mathbf{C}$., and MHCII + CD8a + double positive $\mathbf{D}$ cell types were studied after antigen stimulation to DCs cells from non-transgenic (NT) mice, APP, and APP/PS1 mice genotypes $(n=4$ per group). In studying the CD11c+ cells A., we found significance between the WT and mutant $(22 \mathrm{w})$ in the NT mouse genotype only $(n=4, P<0.05)$. However, significance was found in all three mouse genotypes, between the levels of WT and 22w A $\beta$, in the percentages of CD8a+ cells B., in the percentages of MHCII+peptide+ cells $\mathbf{C}$., and in the percentages of MHCII + CD8a + cells $\mathbf{D} .(n=4, P<0.05)$. 
A

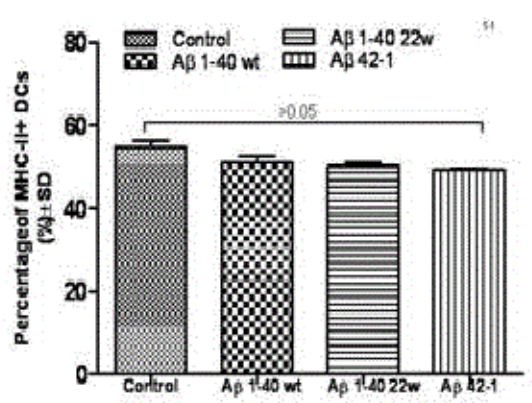

B

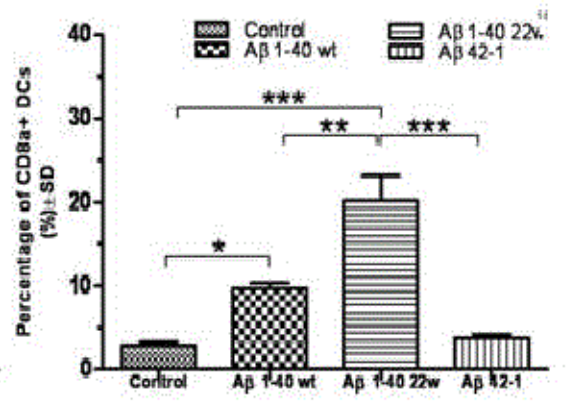

C

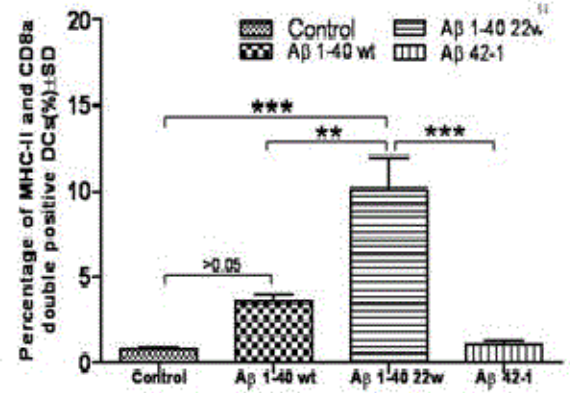

Figure 7: Cell marker induction shows antigen specificity in 30 month old APP/PS1 mice. MHCII+ and CD8a+ Dendritic cells (DCs) in the aged mice were studied by flow cytometry (not shown) after antigen stimulation for 24 hours. There was no significant difference when looking at the percentage uptake of MHCII+ DCs in terms of the different peptides A.. However, significant differences were found in B., when looking at the differences in CD8a+ DCs between the mutant peptide and all over levels $(P<0.05)$. In $\mathbf{C}$., significant differences were also found in $\mathrm{CD} 8 \mathrm{a}^{+}, \mathrm{MHC}-\mathrm{II}+$ double positive DCs when comparing the mutant peptide to all over levels $(P<0.05)$.

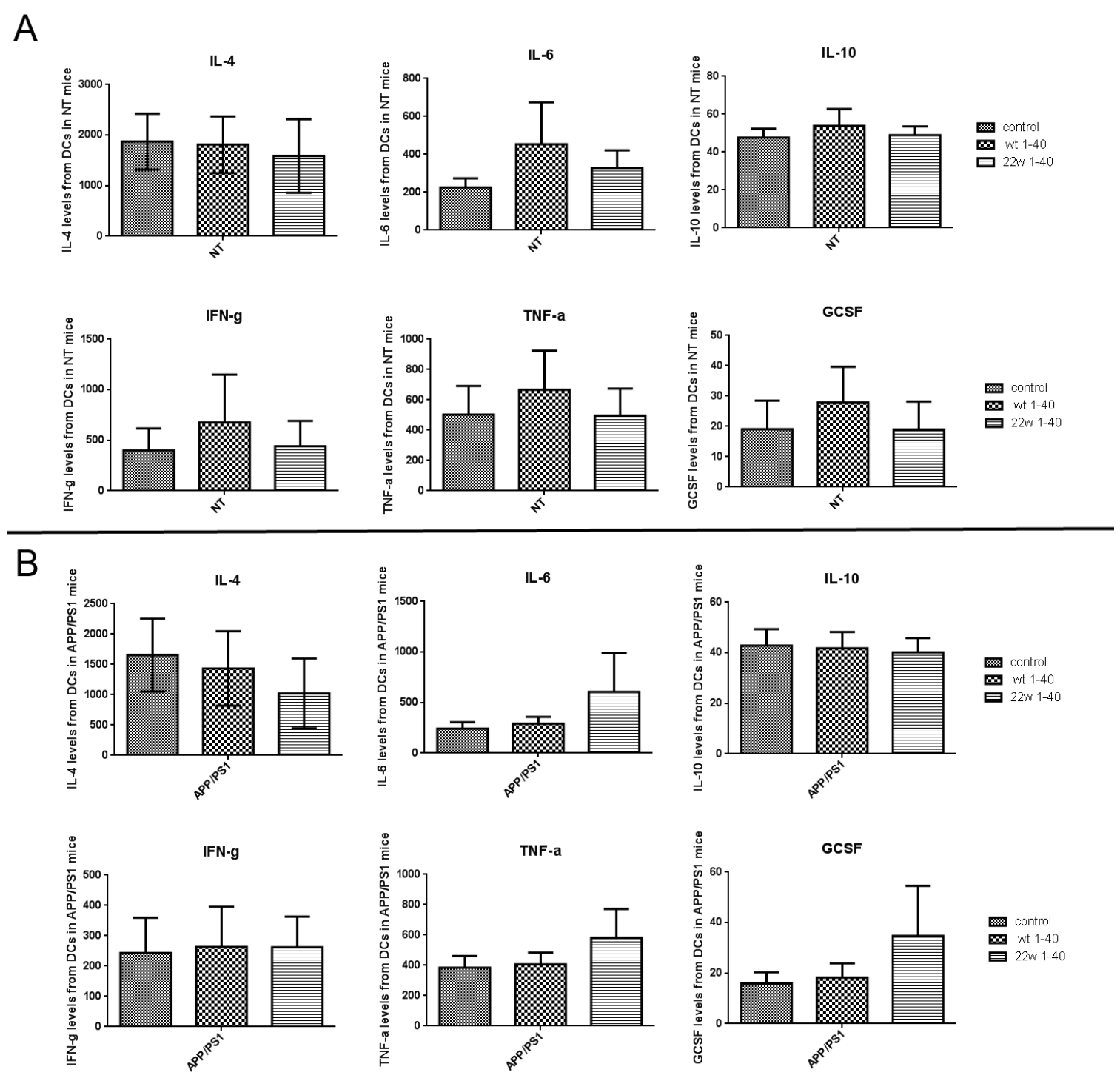

Figure 8: Result of cytokine and chemokine expression profile after antigen stimulation to DCs from different genotype mice. Various cytokine levels of dendritic cells (DCs) were detected with Luminex multiplex assay 24 hours after A $\beta 1-40$ WT or A $\beta 1-40$ 22w stimulation. The cytokines IL4, IL6, IL10, IFN-gamma, TNF-alpha, and G-CSF levels were measured from DCs cell supernatant of non-transgenic mice (NT) A. and APP/PS1 mice B. There are no significant differences found among any of the groupings $(n=4, P>0.05)$. 

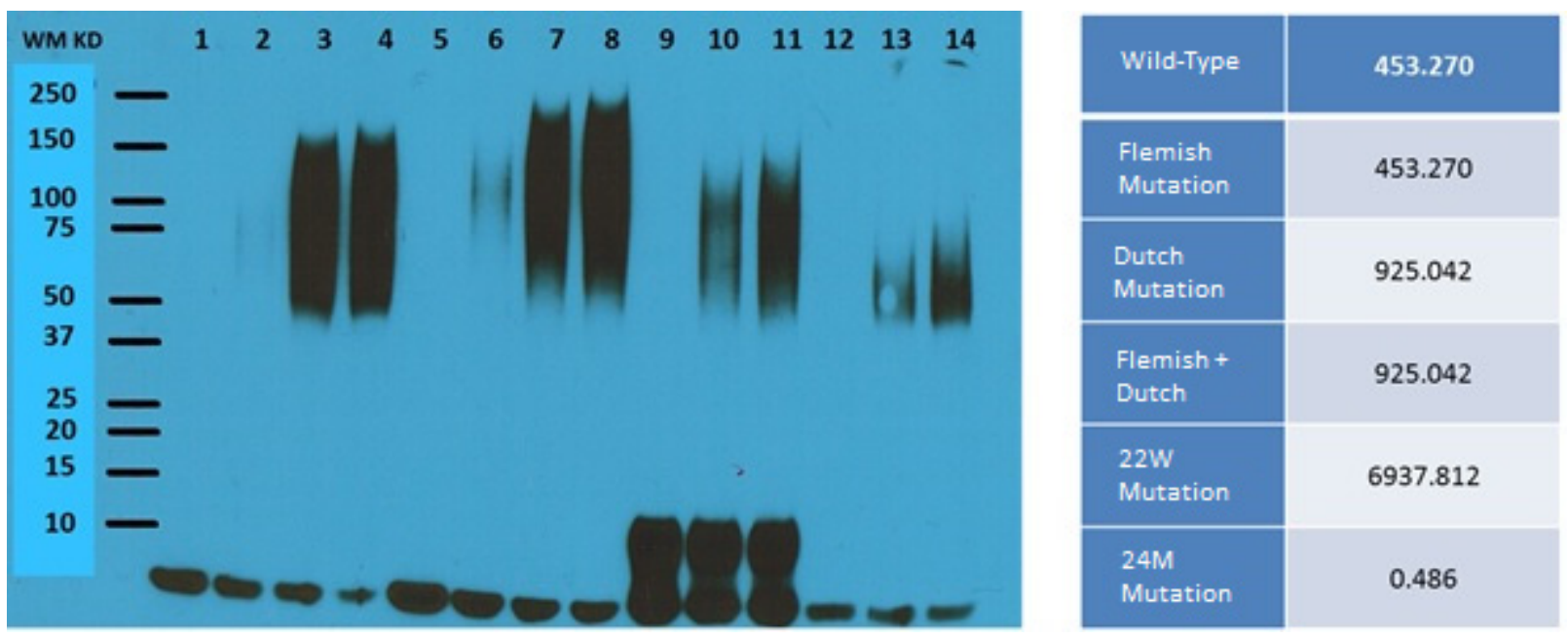

Figure 9: Western Blot results of different types of peptide treatment. Shown is the Western Blot result for different mutations in the beta amyloid peptide. The lanes for the western blot result are as follows (all reconstituted from HFIP treated film): Lane 1, WT A $\beta$ without aggregation; Lane 2-4, WT A $\beta$ aggregated for $3 \mathrm{hr}, 16 \mathrm{hr}$, and $24 \mathrm{hr}$ at $37^{\circ} \mathrm{C}$; Lane 5 , A $\beta$ with Dutch mutation without aggregation; Lane 6-8, A $\beta$ with Dutch mutation aggregated for $3 \mathrm{hr}, 16 \mathrm{hr}$, and $24 \mathrm{hr}$ at $37^{\circ} \mathrm{C}$; Lane $9, \mathrm{~A} \beta$ with a $22 \mathrm{~W}$ mutation without aggregation; Lane $10-11, \mathrm{~A} \beta$ with a $22 \mathrm{~W}$ mutation aggregated for $16 \mathrm{hr}$ and $24 \mathrm{hr}$ at $37^{\circ} \mathrm{C}$; Lane $12, \mathrm{~A} \beta$ with a $24 \mathrm{M}$ mutation without aggregation; Lane $13-14$, A $\beta$ with a $24 \mathrm{M}$ mutation aggregated for $16 \mathrm{hr}$ and $24 \mathrm{hr}$ at $37^{\circ} \mathrm{C}$. On the right are the MHC Class I affinity results for each of the different mutations. Each of the rows is as follows: From Top to Bottom, Wild-type, Flemish, Dutch, PFDM, 22W, and 24M.

excessive inflammation.

The DC activation, in our experiment, is believed to be MHC-I affinity dependent but not specifically peptide conformation related (Figure 9). The lowest affinity mutations (24M mutation) showed the highest levels of aggregation (Lanes 12-14, Figure 9); the WT (Lanes 1-4) demonstrated much pro-aggregation than $22 \mathrm{~W}$ (Lanes 9-11). The WT form of A $\beta$ was also much lower in terms of MHC Class I affinity and failed to sensitize DCs when tested in both BALB/c and APP/PS1 as compared with $22 \mathrm{~W}$ peptide. Inferentially, mutant peptides are likely to effectively activate $\mathrm{CD} 8^{+} \mathrm{T}$-cells. Also the previous notions, that the WT form of $A \beta$ is the largest pro-aggregation form, might not be entirely true, as we have demonstrated that the larger levels of aggregation were exhibited by the mutant peptide (lanes 12 to 14 ) by Western blot.

Our data from DCs and LCs sensitized with different antigens have demonstrated that (1) BMDCs from older mice can be sensitized with a specific antigen to facilitate normal presentation function; peptide-sensitized DCs can be a very potent and effective therapeutic vaccine in agerelated diseases when treated with the proper antigen, (2) mutant $\mathrm{A} \beta$ peptide can stimulate $\mathrm{CD} 8 \alpha^{+} \mathrm{DCs}$ at a much higher level; this novel function may boost immune activity and help $\mathrm{AD}$ patients to withstand progressing AD symptoms. These $22 \mathrm{~W}$ peptide-treated DCs may be used as a safe and effective vaccine method for $\mathrm{AD}$, (3) LCs have a quicker and stronger response to the antigen than DCs; LCs and DCs may have different function in immune reaction, and (4) the differences in sensitization of DCs and LCs to WT and mutant peptides can be utilized for future vaccine design.

\section{MATERIALS AND METHODS}

\begin{abstract}
Animals
Adult (8-week-old) male C57/B6 non-transgenic littermate from APP/PS1 breeding colonies were used. All mice were initially genotyped at the time of weaning, and also before sacrifice. Additional confirmation was done using plasma A $\beta 40$ level. Mice were housed under a 12 hr light-dark cycle, with ad libitum access to rodent chow and water. All described procedures were approved by the IACUC Committee of the University of South Florida. All animals were housed in the vivarium at Byrd Alzheimer's Institute, Tampa, Florida.
\end{abstract}

\section{Reagents}

Florescent-labeled peptides (FAM-A $\beta 1-40$, FAM-A $\beta 1-40$ with mutation at aa22, and $A \beta 42-1)$ were purchased from Biomer Technology (CA, USA); all antibodies for flow cytometry used in were purchased from Biolegend Inc. (CA, USA). The antibodies were: CD3,clone 17A2,CAT 100220;CD4,clone GK 1.5,CAT 100412; CD8a,clone 53-6.7,CAT 100708; CD205,clone NLDC-145,CAT 138208; CD207,clone 4C7,CAT 144203; CD11c,clone N418,CAT 117310; MHC-II, clone M5/114.15.2,CAT 107614; and IFN- $\gamma$, clone XMG 1.2,CAT 505810 . 


\section{Cells harvesting, dendritic cells differentiation and cell culture}

\section{Dendritic Cells (DCs) preparation from mouse bone marrow}

DCs were harvested and prepared as previously described [31]. In brief, non-transgenic mice littermates $(\mathrm{C} 57 / \mathrm{B} 6)$ were euthanatized with carbon dioxide $\left(\mathrm{CO}_{2}\right)$. Leg bones were removed and placed in a dish containing $75 \%$ ethanol for $1 \mathrm{~min}$ and then washed twice with $1 \times \mathrm{PBS}$. Bone ends were removed and the marrow cavity was then flushed with 10\% RPMI-1640 (RPMI containing 10\% FBS) medium. Aspirates were collected in a $50 \mathrm{ml}$ conical tube and then passed through a strainer to separate the cells. The cells were pelleted by centrifugation at $400 \times \mathrm{g}$ for $10 \mathrm{~min}$ at $10^{\circ} \mathrm{C}$, and then $3 \mathrm{ml}$ of ACK buffer $(160 \mathrm{mM}$ $\mathrm{NH}_{4} \mathrm{Cl}, 10 \mathrm{mM} \mathrm{KHCO}$ and $0.1 \mathrm{mM}$ Na-EDTA) added for 60s to lyse red blood cells (RBCs). Then cells were resuspended in $30 \mathrm{ml}$ of RPMI-1640 medium. Afterwards, the cells were transferred to a 6 well-plate containing 3 $\mathrm{ml} 10 \%$ RPMI-1640 and reconstituted to $1 \times 10^{6} \mathrm{cells} / \mathrm{ml}$ in RPMI 1640. Plate was incubated at $37{ }^{\circ} \mathrm{C}$ in a tissue culture incubator.

\section{Isolation of splenocyte}

Freshly acquired spleens were weighed, minced and immediately pushed through a $40 \mu \mathrm{m}$ sieve to obtain a mixed cell suspension. The suspensions were centrifuged (350g, 5min) and supernatant discarded. ACK buffer was added to lyse the red blood cells. $1 \times$ PBS was added to stop the lysis, and the cells counted. The splenocyte suspension was centrifuged $(350 \mathrm{~g}, 5 \mathrm{~min})$ again and suspended in RPMI 1640 (Sigma-Aldrich) with 10\% fetal calf serum

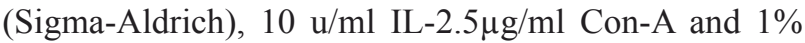
$\beta$-mercaptoethanol, and incubated in $5 \% \mathrm{CO}_{2}$, at $37^{\circ} \mathrm{C}$ in an incubator.

Sensitization of DCs with A $\beta$ peptides and co-culture with splenocytes: DCs differentiation and maturation

a. On day zero, monocytes from bone marrow were collected and cultured under $5 \% \mathrm{CO}_{2}$ in a $37^{\circ} \mathrm{C}$ incubator.

b. After $24 \mathrm{~h}$, all supernatants were aspirated to remove all non-adherent cells (lymphocytes, progenitors, etc.). Cells were washed twice with 1 XPBS gently. Then, fresh 10\% RPMI 1640, containing 10ng/ml murine GMCSF and 10ng/ml IL-4 (BD-Pharmgen, San Jose, CA) and $0.03 \% \beta$-mercaptoethanol, was added.

c. On the fourth day, $1 \mathrm{ml}$ of culture media was removed and replaced with fresh 10\% RPMI 1640 containing $10 \mathrm{ng} / \mathrm{ml} \mathrm{GM-CSF}, 10 \mathrm{ng} / \mathrm{ml} \mathrm{IL}-4$. Wild, mutant types of $A \beta p e p t i d e s$ and $A \beta 42-1$ were added into the designated well at a final concentration of $20 \mu \mathrm{g} / \mathrm{ml}$.

d. On the sixth day, spleen cells were thawed, and washed 3 times with 1XPBS. Afterwards, it was adjusted to $2 \times 10^{6}$ cells $/ \mathrm{ml}$ and cultured in an incubator. e. On the seventh day, $200 \mu 1$ of supernatant was carefully obtained from the DC well and stored in the freezer. Peptide-sensitized DCs were collected and washed with $1 \times$ PBS twice, then re-suspended with $1 \times$ PBS to $1 \times 10^{6} \mathrm{cells} / \mathrm{ml}$. Next, splenocytes with DCs were mixed in a 12 well plate. The proportion was $1: 5$, thus $0.6 \times 10^{6} \mathrm{DC}$ was mixed with $2.4 \times 10^{6}$ spleen cells per well.

f. On the eighth day, $200 \mu 1$ supernatant was again carefully collected from the DC culture, and then stored in the freezer. Then, all cells were harvested and stained with fluorescent labeled antibodies for FCM (flow cytometer) and LSCM (laser scanning confocal microscope).

\section{Epidermal explant culture for LCs}

We employed the method described by Sparber et al. [49] with slight modification. Briefly, mouse ears were removed at the base with scissors and rinsed briefly in $75 \%$ ethanol, then air-dried on sterile gauze for 20 mins. The ears were split into the dorsal and ventral halves (containing the cartilage) with two strong forceps and then the dermal side placed downwards in $0.8 \%$ trypsin solution for 25 mins. After $25 \mathrm{mins}$, the tissue was transferred onto a Petri dish containing $10 \mathrm{ml}$ pure FBS. The epidermis was peeled off and the dermal piece discarded. Epidermal pieces were then cultured in $3 \mathrm{ml}$ complete medium in 6 -well plates for 3 days at $37^{\circ} \mathrm{C}$. Afterwards, the epidermal pieces were removed and the emigrated cells were harvested from the culture medium. Cells were centrifuged at $450 \times \mathrm{g}$ for $5 \mathrm{~min}$ at $4^{\circ} \mathrm{C}$ and then suspended appropriate medium for counting, and usage in subsequent assays.

\section{Sensitizing $L C$ with $A \beta$ peptides}

Cells were cultured for $24 \mathrm{~h}$ in the $\mathrm{CO}_{2}$ incubator, and then used for the following procedure:

On the first day, LCs were transferred into 12-well plate $\left(20 \times 10^{4}\right.$ cells per well).

After $72 \mathrm{~h}, 1 \mathrm{ml}$ of culture media was removed and replaced with fresh 10\% RPMI 1640 containing $10 \mathrm{ng} / \mathrm{ml}$ GM-CSF and $10 \mathrm{ng} / \mathrm{ml} \mathrm{IL-4.} \mathrm{Then,} \mathrm{wild} \mathrm{type} \mathrm{and} \mathrm{mutant}$ type forms of $A \beta$ peptides, as described earlier, were added separately to a final concentration of $20 \mu \mathrm{g} / \mathrm{ml}$.

On the sixth day, $200 \mu$ l of supernatant was carefully collected from the LC well and stored. Afterwards, all cells were harvested, and then stained with fluorescent labeled antibodies for FCM and LSCM analyses.

\section{Cytokines assay (Luminex)}

Supernatants from co-cultures were stored at $-80^{\circ} \mathrm{C}$ after collection until used. A panel of 17 cytokines and chemokines, including IFN- $\gamma$, IL-2, IL-4, IL-10, IL-12, and TGF- $\beta$ were measured using mouse multiplex kits from Affymetrix science(CA, USA). Standard and all samples were prepared according to the manufacture's protocol in a 96-well plate. The plate was read on a Bio- 
PlxMagpix Luminex 200 reader (Bio-Rad, CA, USA), and then the concentration of each analyte calculated based on the generated standard curve.

\section{Flow cytometry assay}

All antibodies for cell labeling were purchased from Biolegend (CA, USA). After 24-hour co-cultured incubation, the cells were harvested and stained in a total volume of $100 \mu \mathrm{l}$ with $5 \mu \mathrm{l}$ different fluorescent labeled antibodies. After $30 \mathrm{~min}$ of incubation at $4 \%$, the cells were fixed in $4 \%$ paraformaldehyde in $1 \times \mathrm{PBS}$ solution. The cells were washed twice in $1 \times \mathrm{PBS}$ and detected with a BD Accuri C6 Flow Cytometer (CA, USA).

\section{Confocal laser scanning microscope}

All antibodies for cell labeling were purchased from Biolegend (CA, USA). After 24-hour co-culture incubation, the cells were harvested and stained in a total volume of $100 \mu \mathrm{L}$ with $5 \mu \mathrm{l}$ different fluorescent labeled antibodies. After $30 \mathrm{~min}$ of incubation at $4 \%$, the cells were fixed in $4 \%$ paraformaldehyde in $1 \times$ PBS. About $1 \times 10^{6}$ cells were collected and cytospinned (1000rpm,10min) onto a slide for confocal imaging with Fluoview FV10i confocal microscope systems (Olympus, PA, USA)

\section{Statistical analysis}

Data are expressed as the mean $\pm \mathrm{SD}$ and analyzed using one-way analysis of variance (ANOVA), followed by Tukey post hoc test using Prism 6.0 (GraphPad Software Inc., San Diego, CA). The level of statistical significance was deemed to be $P<0.05$.

\section{FUNDING}

Funding for this research was through a startup grant provided by the University of South Florida and by the USF Health Byrd Alzheimer's Institute. The funding source has no role in the research other than providing financial support.

\section{CONFLICTS OF INTEREST}

The authors declare no conflicts of interests related to this manuscript.

\section{REFERENCES}

1. Orenstein WA, Bernier RH and Hinman AR. Assessing vaccine efficacy in the field. Further observations. Epidemiologic reviews. 1988; 10:212-241.
2. Goronzy JJ, Fulbright JW, Crowson CS, Poland GA, O'Fallon WM and Weyand CM. Value of immunological markers in predicting responsiveness to influenza vaccination in elderly individuals. Journal of virology. 2001; 75:12182-12187.

3. Goodwin K, Viboud C and Simonsen L. Antibody response to influenza vaccination in the elderly: a quantitative review. Vaccine. 2006; 24:1159-1169.

4. De Vuyst H, Clifford GM, Nascimento MC, Madeleine MM and Franceschi S. Prevalence and type distribution of human papillomavirus in carcinoma and intraepithelial neoplasia of the vulva, vagina and anus: a meta-analysis. International journal of cancer Journal international du cancer. 2009; 124:1626-1636.

5. Lannfelt L, Moller C, Basun H, Osswald G, Sehlin D, Satlin A, Logovinsky V and Gellerfors P. Perspectives on future Alzheimer therapies: amyloid-beta protofibrils - a new target for immunotherapy with BAN2401 in Alzheimer's disease. Alzheimer's research \& therapy. 2014; 6:16.

6. Senior K. Dosing in phase II trial of Alzheimer's vaccine suspended. The Lancet Neurology. 2002; 1:3.

7. Ethell DW, Shippy D, Cao C, Cracchiolo JR, Runfeldt M, Blake B and Arendash GW. Abeta-specific T-cells reverse cognitive decline and synaptic loss in Alzheimer's mice. Neurobiology of disease. 2006; 23:351-361.

8. Cao C, Arendash GW, Dickson A, Mamcarz MB, Lin X and Ethell DW. Abeta-specific Th2 cells provide cognitive and pathological benefits to Alzheimer's mice without infiltrating the CNS. Neurobiology of disease. 2009; 34:6370.

9. Bell D, Young JW and Banchereau J. Dendritic cells. Advances in immunology. 1999; 72:255-324.

10. Banchereau J, Briere F, Caux C, Davoust J, Lebecque S, Liu YJ, Pulendran B and Palucka K. Immunobiology of dendritic cells. Annual review of immunology. 2000; 18:767-811.

11. Louveau A, Smirnov I, Keyes TJ, Eccles JD, Rouhani SJ, Peske JD, Derecki NC, Castle D, Mandell JW, Lee KS, Harris TH and Kipnis J. Structural and functional features of central nervous system lymphatic vessels. Nature. 2015.

12. Mann DM, Brown SM, Owen F, Baba M and Iwatsubo T. Amyloid beta protein (A beta) deposition in dementia with Lewy bodies: predominance of A beta 42(43) and paucity of A beta 40 compared with sporadic Alzheimer's disease. Neuropathology and applied neurobiology. 1998; 24:187194.

13. Agadjanyan MG, Ghochikyan A, Petrushina I, Vasilevko V, Movsesyan N, Mkrtichyan M, Saing T and Cribbs DH. Prototype Alzheimer's disease vaccine using the immunodominant B cell epitope from beta-amyloid and promiscuous T cell epitope pan HLA DR-binding peptide. Journal of immunology. 2005; 174:1580-1586.

14. Cao C, Lin X, Zhang C, Wahi MM, Wefes I, Arendash G and Potter H. Mutant amyloid-beta-sensitized dendritic cells 
as Alzheimer's disease vaccine. J Neuroimmunol. 2008; 200:1-10.

15. McLaurin J, Cecal R, Kierstead ME, Tian X, Phinney AL, Manea M, French JE, Lambermon MH, Darabie AA, Brown ME, Janus C, Chishti MA, Horne P, Westaway D, Fraser PE, Mount HT, et al. Therapeutically effective antibodies against amyloid-beta peptide target amyloid-beta residues 4-10 and inhibit cytotoxicity and fibrillogenesis. Nature medicine. 2002; 8:1263-1269.

16. Johnstone EM, Chaney MO, Norris FH, Pascual R and Little SP. Conservation of the sequence of the Alzheimer's disease amyloid peptide in dog, polar bear and five other mammals by cross-species polymerase chain reaction analysis. Brain research Molecular brain research. 1991; 10:299-305.

17. Hiltunen $\mathrm{M}$, van Groen $\mathrm{T}$ and Jolkkonen J. Functional roles of amyloid-beta protein precursor and amyloid-beta peptides: evidence from experimental studies. Journal of Alzheimer's disease : JAD. 2009; 18:401-412.

18. Zou K, Gong JS, Yanagisawa K and Michikawa M. A novel function of monomeric amyloid beta-protein serving as an antioxidant molecule against metal-induced oxidative damage. The Journal of neuroscience : the official journal of the Society for Neuroscience. 2002; 22:4833-4841.

19. Baruch-Suchodolsky R and Fischer B. Abeta40, either soluble or aggregated, is a remarkably potent antioxidant in cell-free oxidative systems. Biochemistry. 2009; 48:43544370 .

20. Igbavboa U, Sun GY, Weisman GA, He Y and Wood WG. Amyloid beta-protein stimulates trafficking of cholesterol and caveolin-1 from the plasma membrane to the Golgi complex in mouse primary astrocytes. Neuroscience. 2009; 162:328-338.

21. Soscia SJ, Kirby JE, Washicosky KJ, Tucker SM, Ingelsson M, Hyman B, Burton MA, Goldstein LE, Duong S, Tanzi RE and Moir RD. The Alzheimer's disease-associated amyloid beta-protein is an antimicrobial peptide. PloS one. 2010; 5:e9505.

22. Balin BJ, Little CS, Hammond CJ, Appelt DM, WhittumHudson JA, Gerard HC and Hudson AP. Chlamydophila pneumoniae and the etiology of late-onset Alzheimer's disease. Journal of Alzheimer's disease : JAD. 2008; 13:371-380.

23. Lemere CA, Maier M, Jiang L, Peng Y and Seabrook TJ. Amyloid-beta immunotherapy for the prevention and treatment of Alzheimer disease: lessons from mice, monkeys, and humans. Rejuvenation research. 2006; 9:7784.

24. Levy E, Carman MD, Fernandez-Madrid IJ, Power MD, Lieberburg I, van Duinen SG, Bots GT, Luyendijk W and Frangione B. Mutation of the Alzheimer's disease amyloid gene in hereditary cerebral hemorrhage, Dutch type. Science. 1990; 248:1124-1126.

25. Van Broeckhoven C, Haan J, Bakker E, Hardy JA, Van
Hul W, Wehnert A, Vegter-Van der Vlis M and Roos RA. Amyloid beta protein precursor gene and hereditary cerebral hemorrhage with amyloidosis (Dutch). Science. 1990; 248:1120-1122.

26. Cras P, van Harskamp F, Hendriks L, Ceuterick C, van Duijn CM, Stefanko SZ, Hofman A, Kros JM, Van Broeckhoven C and Martin JJ. Presenile Alzheimer dementia characterized by amyloid angiopathy and large amyloid core type senile plaques in the APP 692Ala $\longrightarrow$ Gly mutation. Acta Neuropathol. 1998; 96:253-260.

27. Tang TC, Hu Y, Kienlen-Campard P, El Haylani L, Decock M, Van Hees J, Fu Z, Octave JN, Constantinescu SN and Smith SO. Conformational changes induced by the A21G Flemish mutation in the amyloid precursor protein lead to increased A $\beta$ production. Structure. 2014; 22:387-396.

28. Shahnawaz M, Sharoar MG, Shin SY and Park IS. Wildtype, Flemish, and Dutch amyloid- $\beta$ exhibit different cytotoxicities depending on $A \beta 40$ to $A \beta 42$ interaction time and concentration ratio. J Pept Sci. 2013; 19:545-553.

29. Kutzler MA, Cao C, Bai Y, Dong H, Choe PY, Saulino V, McLaughlin L, Whelan A, Choo AY, Weiner DB and Ugen KE. Mapping of immune responses following wildtype and mutant ABeta42 plasmid or peptide vaccination in different mouse haplotypes and HLA Class II transgenic mice. Vaccine. 2006; 24:4630-4639.

30. Morgan D, Diamond DM, Gottschall PE, Ugen KE, Dickey C, Hardy J, Duff K, Jantzen P, DiCarlo G, Wilcock D, Connor K, Hatcher J, Hope C, Gordon M and Arendash GW. A beta peptide vaccination prevents memory loss in an animal model of Alzheimer's disease. Nature. 2000; 408:982-985.

31. Cao C, Lin X, Wahi MM, Jackson EA and Potter H, Jr. Successful adjuvant-free vaccination of BALB/c mice with mutated amyloid beta peptides. BMC Neurosci. 2008; 9:25.

32. Aarli J. Role of cytokines in neurological disorders. Curr Med Chem. 2003; 10:1931-1937.

33. Appel SH. CD4+ $\mathrm{T}$ cells mediate cytotoxicity in neurodegenerative diseases. J Clin Invest. 2009; 119:13-15.

34. Bonotis K, Krikki E, Holeva V, Aggouridaki C, Costa V and Baloyannis S. Systemic immune aberrations in Alzheimer's disease patients. J Neuroimmunol. 2008; 193(1-2):183-187.

35. Bonifati D and Kishore U. Role of complement in neurodegeneration and neuroinflammation. Mol Immunol. 2007; 44:999-1010.

36. Wilcock DM, Rojiani A, Rosenthal A, Subbarao S, Freeman MJ, Gordon MN and Morgan D. Passive immunotherapy against Abeta in aged APP-transgenic mice reverses cognitive deficits and depletes parenchymal amyloid deposits in spite of increased vascular amyloid and microhemorrhage. J Neuroinflammation. 2004; 1:24.

37. Britschgi $\mathrm{M}$ and Wyss-Coray $\mathrm{T}$. Systemic and acquired immune responses in Alzheimer's disease. Int Rev Neurobiol. 2007; 82:205-233.

38. Britschgi M and Wyss-Coray T. Immune cells may fend off 
Alzheimer disease. Nature medicine. 2007; 13(4):408-409.

39. Timmerman JM and Levy R. Dendritic cell vaccines for cancer immunotherapy. Annual review of medicine. 1999; 50:507-529.

40. Kugler A, Stuhler G, Walden P, Zoller G, Zobywalski A, Brossart P, Trefzer U, Ullrich S, Muller CA, Becker V, Gross AJ, Hemmerlein B, Kanz L, Muller GA and Ringert RH. Regression of human metastatic renal cell carcinoma after vaccination with tumor cell-dendritic cell hybrids. Nature medicine. 2000; 6:332-336.

41. Luo Z, Li J, Nabar NR, Lin X, Bai G, Cai J, Zhou SF, Cao $\mathrm{C}$ and Wang J. Efficacy of a therapeutic vaccine using mutated $\beta$-amyloid sensitized dendritic cells in Alzheimer's mice. J Neuroimmune Pharmacol. 2012; 7:640-655.

42. Nabar NR, Yuan F, Lin X, Wang L, Bai G, Mayl J, Li Y, Zhou SF, Wang J, Cai J and Cao C. Cell therapy: a safe and efficacious therapeutic treatment for Alzheimer's disease in APP+PS1 mice. PloS one. 2012; 7:e49468.

43. Cao C, Lin X, Wahi MM, Jackson EA and Potter H. Successful adjuvant-free vaccination of BALB/c mice with mutated amyloid beta peptides. BMC Neurosci. 2008; 9:25.

44. Cao C, Lin X, Jackson EA, Potter H. Successful adjuvantfree vaccination with mutant amyloid beta peptides. BMC Neurosci. 2006; In-Press.

45. Wick G and Grubeck-Loebenstein B. Primary and secondary alterations of immune reactivity in the elderly: impact of dietary factors and disease. Immunological reviews. 1997; 160:171-184.

46. Castle SC. Clinical relevance of age-related immune dysfunction. Clinical infectious diseases : an official publication of the Infectious Diseases Society of America. 2000; 31:578-585.

47. Chorro L, Sarde A, Li M, Woollard KJ, Chambon P, Malissen B, Kissenpfennig A, Barbaroux JB, Groves R and Geissmann F. Langerhans cell (LC) proliferation mediates neonatal development, homeostasis, and inflammationassociated expansion of the epidermal LC network. The Journal of experimental medicine. 2009; 206:3089-3100.

48. Sparber F. Langerhans cells: an update. Journal der Deutschen Dermatologischen Gesellschaft $=$ Journal of the German Society of Dermatology : JDDG. 2014; 12:11071111.

49. Sparber F, Tripp CH, Hermann M, Romani N and Stoitzner P. Langerhans cells and dermal dendritic cells capture protein antigens in the skin: possible targets for vaccination through the skin. Immunobiology. 2010; 215:770-779 